\title{
EDUCAÇÃO E DIREITOS HUMANOS: EM BUSCA DA DEMOCRACIA
}

Henrique Miguel de Lima Silva, Universidade Federal da Paraíba - UFPB,

Henrque.miguel.91@gmail.com

Danielli Cristina de Lima Silva, Universidade Federal da Paraíba - UFPB

limaanacrisdani@gmail.com

Márcio Rijoan Albuquerque Cavalcante, Centro Universitário de João Pessoa - UNIPÊ

marciorijoan@hotmail.com

\section{RESUMO}

O presente artigo propõe a discorrer sobre as contribuições dos direitos humanos e das teorias sociointeracionistas, na vertente crítica, para o desenvolvimento de práticas críticas de ensino que, por sua vez, democratizem o ensino e, de fato, ouça as vozes do sul (MOITA-LOPES, 2009). Partimos do pressuposto de que o ensino só é democrático quando leva em consideração os princípios contidos na Declaração Universal dos Direitos Humanos (ONU, 2009). De forma mais específica, discorreremos sobre as perspectivas de ensino, fazendo um breve traçado historiográfico dessas concepções, bem como suas implicações para a prática docente. Em seguida, refletiremos sobre o ensino crítico e emancipador, pautados em Freire (1996, 1998, 2000), bem como em Moita-Lopes (2009) e Kleiman (2009,2010,2012,2014) por compreenderem os espaços formais de ensino enquanto agências de letramento e promoção a cidadania. Optamos pela metodologia bibliográfica (LAKATOS, 2008) por explicitar diretamente o estado da arte da temática em questão, bem como oferecer novos caminhos teórico-epistemológicos para desenvolvimentos de pesquisa na área de educação e direitos humanos. Não podemos esquecer a educação, além de ser um direito universal e, no nosso cenário nacional, obrigação do Estado (BRASIL, 1988), pouco tem sido feito para que os processos educativos sejam, de fato, democráticos. Ressaltamos que embora os documentos oficiais de ensino (BRASIL, 1996, 1998, 2005, 2014) preconizem que as práticas de ensino devam ser situadas ao contexto dos educandos e ainda oferece-lhes base científica para resolução dos problemas e conflitos sociais com base no conhecimento crítico, ainda estamos longe dessa almejada realidade. Dessa maneira, esperamos que tais reflexões possam ser colocadas em prática uma vez que somente um ensino baseado na práxis da autonomia poderá efetivar os princípios democráticos assegurados pelos direitos humanos.

PALAVRAS-CHAVE: Educação, Direitos Humanos, Democracia.. 